\title{
Charcot-Marie-Tooth Disease Type 2D
}

National Cancer Institute

\section{Source}

National Cancer Institute. Charcot-Marie-Tooth Disease Type 2D. NCI Thesaurus. Code C122659.

Charcot-Marie-T ooth disease inherited in an autosomal dominant pattern. It is caused by mutations in the GARS gene. It results in axonal peripheral neuropathy. 